\title{
HISTORICAL LAND COVER ALONG THE DEEP FORK RIVER: AN ANALYSIS OF VEGETATION COMPOSITION AND DISTRIBUTION OF THE DEEP FORK NATIONAL WILDLIFE REFUGE, OKMULGEE COUNTY, OKLAHOMA, CIRCA 1897
}

\author{
Bruce Hoagland \\ Oklahoma Natural Heritage Inventory and \\ Department of Geography and Environmental Sustainability \\ University of Oklahoma \\ Norman, OK 73019 \\ bhoagland@,ou.edu \\ Rick Thomas \\ Daryn Hardwick \\ Department of Geography and Environmental Sustainability \\ University of Oklahoma \\ Norman, OK 73019
}

Keywords: Deep Fork River, Public Land Survey, historical land cover, bearing trees

\begin{abstract}
North American vegetation has been extensively modified by human activity. Restoring the landscape to past conditions is a strategy for species conservation, but this requires access to reliable data that describes those conditions. Here we use plat and bearing tree data collected during the Public Land Survey of 1897 (PLS) to describe the vegetation at the Deep Fork National Wildlife Refuge. We digitized five township plats and recorded data for all bearing trees. Of the six land cover types, forest (67\%) and grassland $(29 \%)$ were the most extensive. Surveyors recorded 708 individual bearing trees. Post oak (Quercus stellata Wangenh.) (199 stems), red oak (Q. rubra L.) (140), and blackjack oak (Q. marilandica Münchh) (92) were the most common trees. Some proportion of the trees identified as red oak were most likely black oak (Quercus velutina Lam.) and/or Shumard oak (Quercus shumardii Buckley var. shumardii). Eastern red cedar (Juniperus virginiana L.) was not recorded as a bearing tree but was recorded in the line notes. At the time of the PLS survey, the study area exhibited modification. Although the PLS began in Oklahoma in 1870, the Creek Nation was surveyed beginning in 1896.

\section{INTRODUCTION}

North American vegetation has been extensively modified or obliterated by human activity, which is certainly the case in Oklahoma. The extent and pace of these changes began to accelerate in the $19^{\text {th }}$ century. Although the use of fire and clearing for settlements by the original occupants of the continent affected

vegetation (Cronon 1983), the rate accelerated following westward expansion by Euro-Americans (Flannery 2002; Goudie 2005). The result has been a significant loss of and fragmentation of habitat which exacerbates the likelihood of extinction for many species (Turner and Meyer 1991; Hanski 2011). To stem the loss of both, ecologists have turned to the practice of habitat restoration. But this begs the
\end{abstract}


question, what were the environmental conditions and habitat composition in early North American history? To address this question, many have turned to the records of the Public Land Survey (PLS), which was established by passage of the Land Ordinance on 20 May 1785 by the Continental Congress (White 1983; Brothers 1991).

The General Land Office (GLO) was responsible for conducting the PLS. The Land Ordinance required that areas in the U.S. territories be delineated into Congressional Townships of 36 mile $^{2}$ (9,323.96 hectares), each of which was further subdivided into 36 sections of 1 mile $^{2}$. Surveyors were instructed to describe the vegetation and physical features encountered during the survey in the form of written notes and on mapped township plats (Brothers 1991; Stewart 1935). The surveyors were also required to mark "witness trees" to aid in the relocation of survey landmarks. The procedure involved measuring the distance from the survey landmark to the nearest trees: one tree in each of four quarters where section-lines intersect and one on opposite sides of the survey line for quarter sections (Figure 1). The species name (typically common name was recorded, but scientific binomials were provided by surveyors in some states), stem diameter, and distance were recorded for each witness tree (Whitney and DeCant 2001).

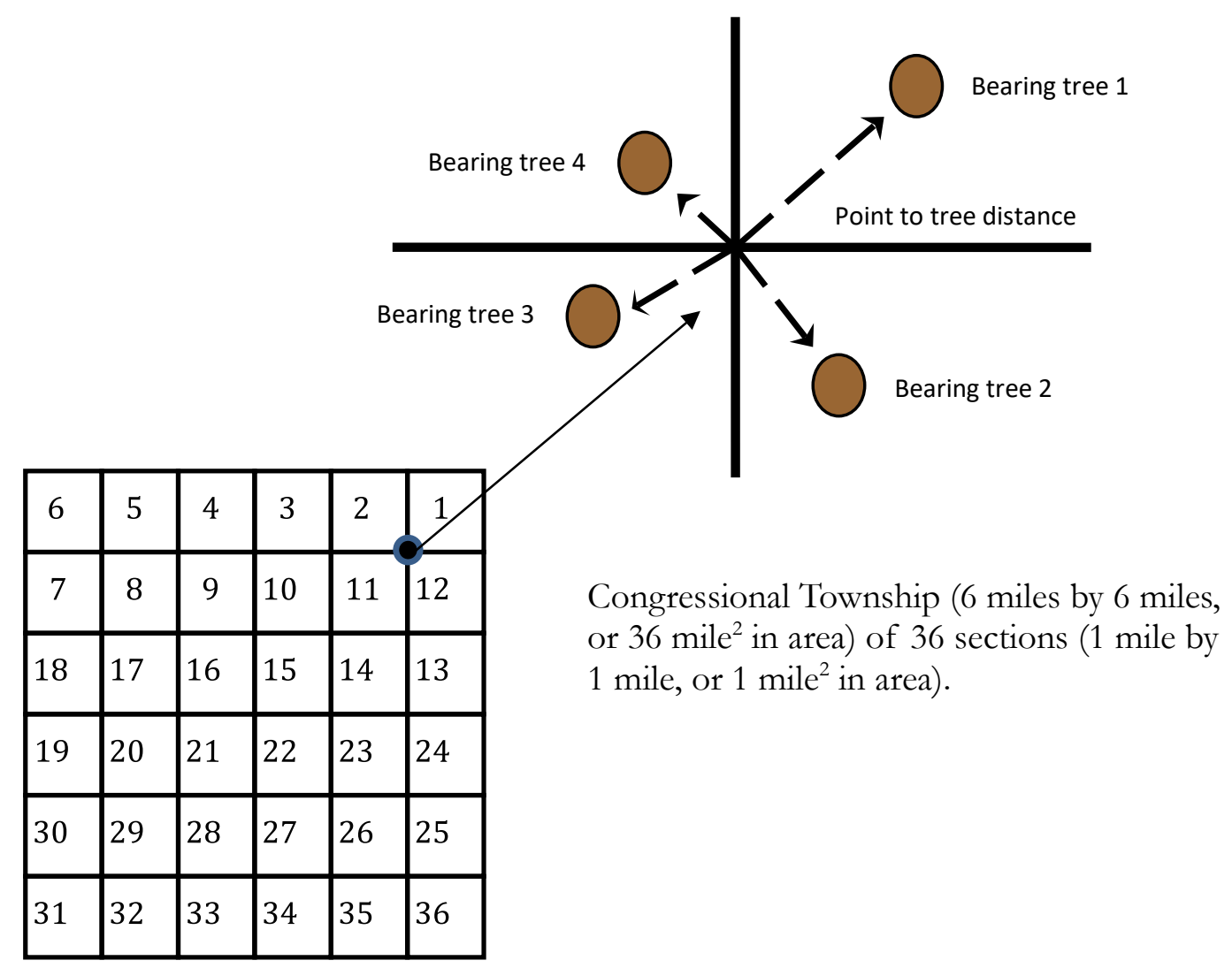

Figure 1 Process for locating bearing trees employed by surveyors of the Public Land Survey. As surveyors established quarter section lines, they were required to stop at half mile intervals and measure the distance and diameter of trees in adjacent sections and record an identification. This information was used to relocate section corners and assist settlers by providing them the legal description for their land claims. 
Although the intent of the PLS was to parcel land and not to gather ecological data, these records have been useful for evaluating the composition and distribution of vegetation and land-use of the past (Bourdo 1956; Whitney and DeCant 2001). As such, the PLS data can be used to develop a baseline of environmental conditions prior to extensive EuroAmerican settlement and aid in the analysis of land cover change over time (Galatowitsch 1990; Schulte and Mladenoff 2001).

The PLS began in Oklahoma with the establishment of the Initial Point in the Arbuckle Mountains in 1871 (Hoagland 2006). Though lagging behind other states in the analysis of PLS data (Fagin and Hoagland 2002), recent studies have analyzed these data for locations in the Cross Timbers region. Each of these studies addressed questions about the composition and structure of Cross Timbers vegetation in the 1870 s and whether native-invasive species were detectable in the data (i.e., Juniperus virginiana L. or Prosopis glandulosa Torr.). Two of these studies focused on the Arbuckle Mountains region. Shutler and Hoagland (2004) analyzed the witness tree data for Carter County in 1871 and found that only one "cedar" tree (Juniperus ashei Buchholz or J. virginiana) was reported. Fagin and Hoagland (2010) modeled the distribution of witness trees in relation to geology and soils in the Arbuckle Mountains using the PLS data from 1871 and a second PLS dataset from 1890 and discovered four individual cedars reported in the bearing tree data of the first survey and seven in the second.

Hoagland et al. (2013) analyzed PLS data from the Wichita Mountains National Wildlife Refuge and found Juniperus virginiana and Prosopis glandulosa, both a modern ecological and economic threat (Van Auken 2000), were present in the 1870s and 1890s. Thomas (2010) used the PLS plats and witness tree data to investigate the role of rivers as landscape barriers to the spread of fire and the resulting difference in vegetation composition.

Given the ever-changing nature of bottomland and upland forest vegetation in Oklahoma, the objective of this study was to analyze PLS records for the Deep Fork National Wildlife Refuge (DFNWR) and adjacent areas to establish a baseline of landscape and vegetation conditions for refuge personnel. Although the PLS started in the 1870s in present day Oklahoma (Hoagland 2006), Creek tribal lands were not surveyed until the 1890s, by which time landscape transformation was well underway. We used qualitative data consisting of written timber descriptions, each of which lists predominant and cooccurring species and the physical setting in which the surveys were conducted.

Quantitative data consisted of both bearing tree records (e.g., point-to-plant distance, diameter-at-breast height) and plats for determination of land cover types and their extent. The bearing tree data provides insight regarding the species composition and vegetation structure (e.g., basal area and stem density).

\section{STUDY AREA}

The Deep Fork National Wildlife Refuge $\left(096^{\circ} 00\right.$ '21.6'W to $095^{\circ} 54^{\prime} 39.6^{\prime \prime} \mathrm{W}$ and $35^{\circ} 34^{\prime} 51.6^{\prime \prime} \mathrm{N}$ to $35^{\circ} 32^{\prime} 24.1^{\prime \prime} \mathrm{N}$ ) (Figure 2) was established in 1993 to protect 3,925 ha of forested and herbaceous emergent wetlands habitats (United States Fish and Wildlife Service 2019). The ecological significance of the bottomland hardwood forests of the Deep Fork River has been long recognized (Brabander et al. 1985). The DFNWR is located in the Subtropical Humid (Cf) climate zone (Trewartha 1968), with warm (mean July temperature $27.28^{\circ} \mathrm{C}$ ) and humid summers and relatively short and mild (mean January temperature $2.68^{\circ} \mathrm{C}$ ) winters. Mean annual 
precipitation is $110 \mathrm{~cm}$ (Oklahoma Climatological Survey 2019).

The DFNWR lies within the Osage Plains section of the Central Lowlands province (Hunt 1974) and within the Eastern Sandstone Cuesta Plains province of Oklahoma. The surface geology is Pennsylvanian sandstones and quaternary alluvium (Curtis et al. 2008). Soil associations at the DFNWR are predominantly the Verdigris-LightningPulaski association (nearly level, deep, loamy floodplain soils) and the Konawa-Stidham (nearly level to sloping, deep, sandy soils). The Hector-Hartsells (very gently sloping to steep, moderately deep soils on forested uplands) and the Taloka (nearly level, deep soils on prairies) occupy the uplands (Sparwasser et al. 1968).

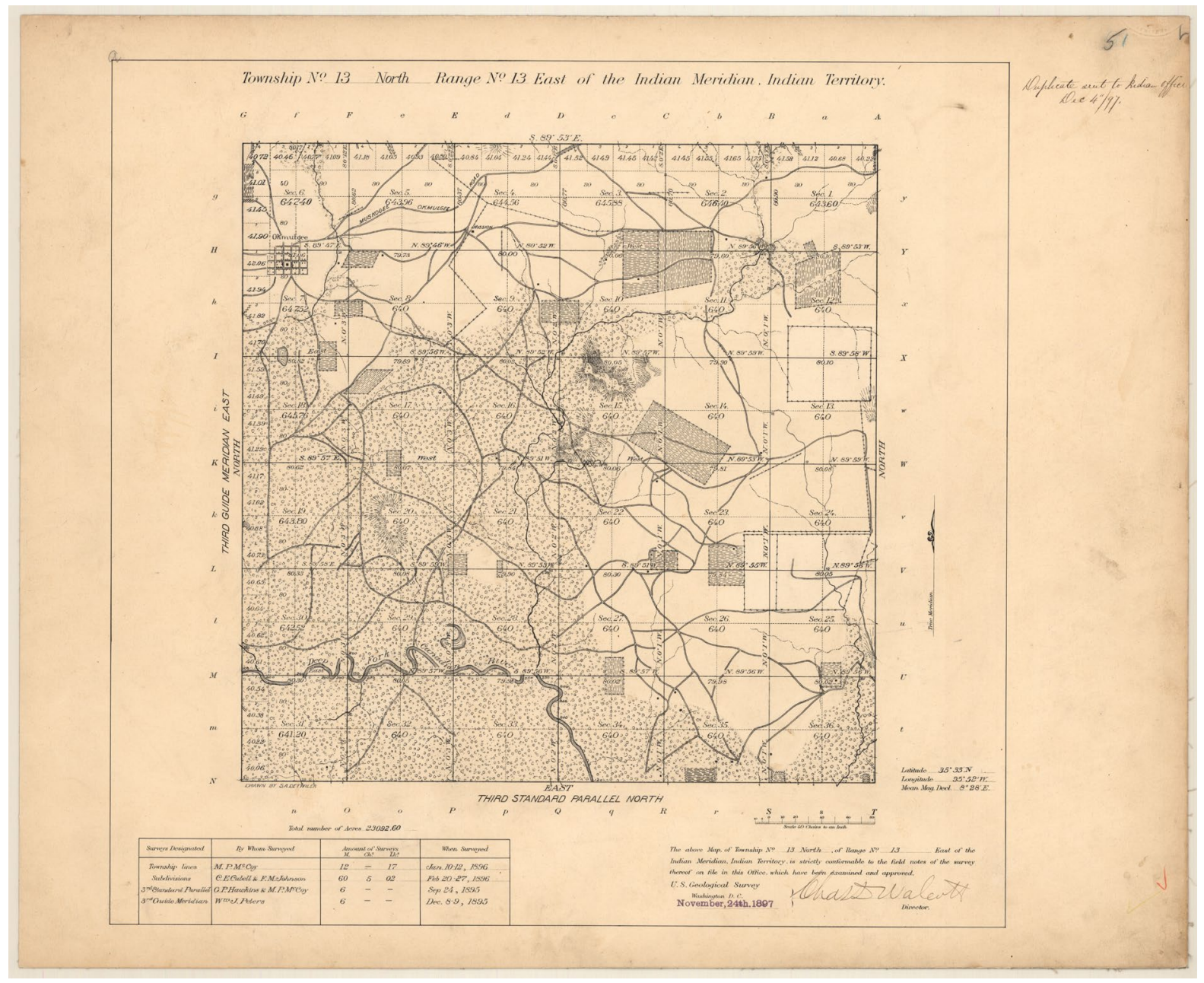

Figure 2 An example of a plat as mapped by the General Land Office in 1896 that includes portions of the Deep Fork National Wildlife Refuge. The Township is 13 north and Range 13 east of the Indian Meridian. Features on the plat include Okmulgee in the northwest corner, the Deep Fork of the Canadian River, ponds, agricultural field, fencing, and forest woodlands. Source: General Land Office records (www.glorecords.blm.gov) 
Duck and Fletcher (1943) mapped the potential natural vegetation (or as they wrote Game Types) of Okmulgee County as post oak-blackjack oak forest and tallgrass prairie, with a distinct band of bottomland forest following the Deep Fork River. Duck and Fletcher describe the post oak-blackjack oak forest as "The overstory is largely composed of post oak (Quercus stellata), blackjack oak (Q. marilandica), and black hickory (Carya texana) with the percent of blackjack oak increasing in the composition as one moves west through the Post Oak Blackjack Game Type. The understory is made up of little bluestem (Schizachyrium scoparium), big bluestem (Andropogon gerardii), and other species depending upon the site." The tallgrass prairie "consists of a mixture of such species as big bluestem (Andropogon gerardii), little bluestem (Schizachyrium scoparium), Indian grass (Sorghastrum nutans), switch grass (Panicum virgatum), and silver beard grass (Bothriochloa saccharoides), in the eastern portions of the type..."

As mapped by Duck and Fletcher, the bottomland forest type extends from southeast Oklahoma to the Panhandle as one unit. In the text of the report, however, they describe regional variation in vegetation composition. The following text most closely describes the bottomland forest communities of Okmulgee County: "Typical stream growth in central Oklahoma within the Tallgrass Prairie Game Type consists of American elm (Ulmus americana), chinquapin oak (Quercus mublenbergii), post oak (Quercus stellata), blackjack oak (Quercus marilandica), hackberry (Celtis laevigata and/or C. occidentalis), chittamwood (Bumelia lanuginosa) [Sideroxylon lanuginosum Michx.], cottonwood (Populus deltoides), chickasaw plum (Prunus angustifolia), fragrant sumac (Rhus trilobata Nutt.) [R. aromatica Aiton], smooth sumac (Rhus glabra), and rough leafed dogwood (Cornus drummondii). Black oaks, pecan (Carya illinoensis) [C. illinoinensis (Wangenh.) K. Koch], sycamore (Platanus occidentalis), bitternut (Carya cordiformis) and walnut (Juglans nigra) are more common southward and eastward." It should be noted that in regard to forest vegetation, many floristic elements of the eastern Oak-Hickory forest and southern bottomland forest flora are present in the study area.

The land-use history of the county has obscured some of the patterns of the historic vegetation. Clearing and conversion to agriculture of the bottomland forests along the Deep Fork River began in the 19th century, with restricted clearing following removal of the Creek Nation to Indian Territory. The rate of change accelerated following passage of the Dawes Act and the allotment of tribal lands. In the mid-20th century, land abandonment allowed some areas to return to Quercus palustris-Carya illinoinensis/Ilex decidua and Ulmus rubra-Celtis laevigata-Fraxinus pennsylvanica bottomland forests (Hoagland 2000). Many hectares in the area are still used for pasturage, much of which was converted from native grasses to Schedonorus arundinaceus (Schreb.) Dumort. (Sparwasser et al. 1968).

\section{MATERIALS AND METHODS}

The PLS records provide three important sources of information, each of which was utilized here: township plats, witness or bearing tree records, and line summaries. The plats and the Field Notes of the Survey were acquired from the Bureau of Land Management (www.glorecords.blm.gov) for the townships 12N 12E (survey date: 1897), $12 \mathrm{~N} 13 \mathrm{E}$ (1898), 13N 12E (1897), 13N 13E (1897), and 14N 12E (1897).

Plats

Township plats (see Figure 2) were georeferenced and digitized using ArcGIS Pro. Features that were digitized from a plat were attributed to one of the following data layers: vegetation (forest, grassland, and 
wetland), hydrology (streams, rivers, springs, and ponds), agriculture (cultivated fields), transportation (roads, trails, and railroads), and settlement (residences, schools, and other cultural features). Once a township was digitized, each data layer was edited, attributed, and joined with adjacent plats. FRAGSTATS (McGarigal et al. 2012) calculates landscape metrics from geospatial data and was used to determine landscape/land cover composition and patterns. For this study, area of a land cover type, number of patches, mean patch size, and patch size standard deviation were calculated. The term patch refers to individual polygons or occurrences of a land cover type. Class area is a measure of the total area occupied by a particular land cover type, number of patches is a count of individual occurrences of a given land cover type, and mean patch size is an average value of the number of patches for a land cover type.

\section{Bearing Trees}

The bearing tree data were used to determine which woody plant species were present and to calculate the stand structure metrics of basal area (BA), the proportion of stems of one species to the total number of stems (PS), and an importance value (IV). Note that biases toward larger trees have been identified in the surveyor's selection of bearing trees (Bourdo 1956). We did not calculate, however, stand density (number of stems or individual tree trunks per unit area). Previous literature employing PLS data have calculated tree density using the point-center-quarter and other "plotless" methods (Schulte and Mladenoff 2001). These methods were intended to quickly collect data using transects from points at regular intervals in distinct forest types (Cottam and Curtis 1956). The PLS collected data at intervals of 0.5 mile (804.7 m), crossing multiple plant community types and environmental gradients. In addition, the points sampled by the PLS represent a township, an area of 36 mile $^{2}$ (9,323.96 hectares). Finally, it is important to remember that the PLS data were not collected to characterize ecological communities or forest stand demographics, but they are the best available data for quantitative analysis of woody plant communities of the past.

Basal area $(\mathrm{BA})$ is a measure of the cross-sectional area of each tree trunk within a given area. We used tree diameter data recorded by the PLS to calculate BA according to Wenger (1984) for each species, using the formula Area $=\Pi r^{2}$.

Relative Basal Area (RBA) was calculated as

$\mathrm{RBA}=\Sigma \mathrm{BA}_{\mathrm{I}} / \Sigma \mathrm{BA}_{\mathrm{T}} \mathrm{X} 100$,

where $\mathrm{BA}_{\mathrm{I}}$ is the total $\mathrm{BA}$ of a species and $\mathrm{BA}_{\mathrm{T}}$ is the total $\mathrm{BA}$ of all species.

We calculated the proportion of stems (PS) as the following formula:

$$
\mathrm{PS}=\sum \mathrm{S}_{\mathrm{I}} / \Sigma \mathrm{S}_{\mathrm{T}} \mathrm{X} 100 \text {, }
$$

where $S_{I}$ is the number of stems of a species and $S_{T}$ is the total number of stems of all species.

The IV is a measure of the predominance of species in a dataset or at a site and in this study is the sum of RBA + PS.

\section{Line Notes and Township Summaries}

Line summaries provide supplemental information that facilitates the development of a thorough description of ecological conditions at the time of the survey. Unlike the bearing tree and plat data, these are narrative statements. We parsed the line descriptions into three categories: surface, vegetation, and soils. Surveyors noted the surface or topography of an area in a broad sense, using terms such as level, hilly, or rolling. The vegetation descriptions were typically a list of taxa present, with occasional notations as to which were more 
common. The protocol for soil description is rather obscure and the categories undefined. Typically, a surveyor ranked the soil on a scale of 1-4 and occasionally supplied an adjective such as sandy or rocky. Rarely were other details presented. It is important to recall, however, that this information was intended to inform the
General Land Office and settlers of agricultural potential and not ecological conditions. Township descriptions presented the same three categories of information, with additional remarks about settlement and other aspects of the township as a whole.

Table 1 Landscape metrics calculated for the land cover in the townships encompassing the Deep Fork National Wildlife Refuge, Okmulgee County, Oklahoma

\begin{tabular}{lcccc}
\hline Landcover & $\begin{array}{c}\text { Class Area } \\
\text { (ha) }\end{array}$ & $\begin{array}{c}\text { Number } \\
\text { of Patches }\end{array}$ & $\begin{array}{c}\text { Mean Patch Size } \\
\text { (ha) }\end{array}$ & $\begin{array}{c}\text { Patch Size Standard } \\
\text { Deviation }\end{array}$ \\
\hline Forest & 28849.7 & 3.0 & 9616.6 & 13598.6 \\
Grassland & 12393.2 & 27.0 & 459.0 & 904.4 \\
Agricultural & 910.0 & 55.0 & 16.5 & 23.4 \\
fields & 643.7 & 13.0 & 49.5 & 91.4 \\
Wetland & 47.9 & 4.0 & 12.0 & 12.4 \\
Slough & 75.5 & 26.0 & 2.9 & 3.3 \\
Lake & 42920.0 & 128.0 & & \\
\hline Total & & & & \\
\hline
\end{tabular}

\section{RESULTS AND DISCUSSION}

Plats

Of the six land cover categories appearing on the plats, forest and woodland vegetation constituted $67 \%$ of the landcover in the study area for 1897 (Table 1). Approximately one third of the study area was grassland vegetation. No other category exceeded $3.0 \%$ of the total area. Regarding the categories presented in the map legend (Figure 3), two points need to be made. First, as noted earlier, the study area lies on the eastern flank of the post oak-blackjack oak forest (Duck and Fletcher 1943). This region is known colloquially as the Cross
Timbers, a mosaic of forest, woodland, and grassland vegetation. Second, the map category "forest and woodland" used here was not employed by the PLS surveyors. This designation was adopted because within the Cross Timbers both forest and woodland vegetation were present, probably on south and west facing slopes (Hoagland et al. 1999). A similar issue arises with the term "grassland". The surveyors use the term prairie, but given the degree of settlement in the townships analyzed, areas of grassland were likely grazed by livestock, as were the adjacent woodlands. 


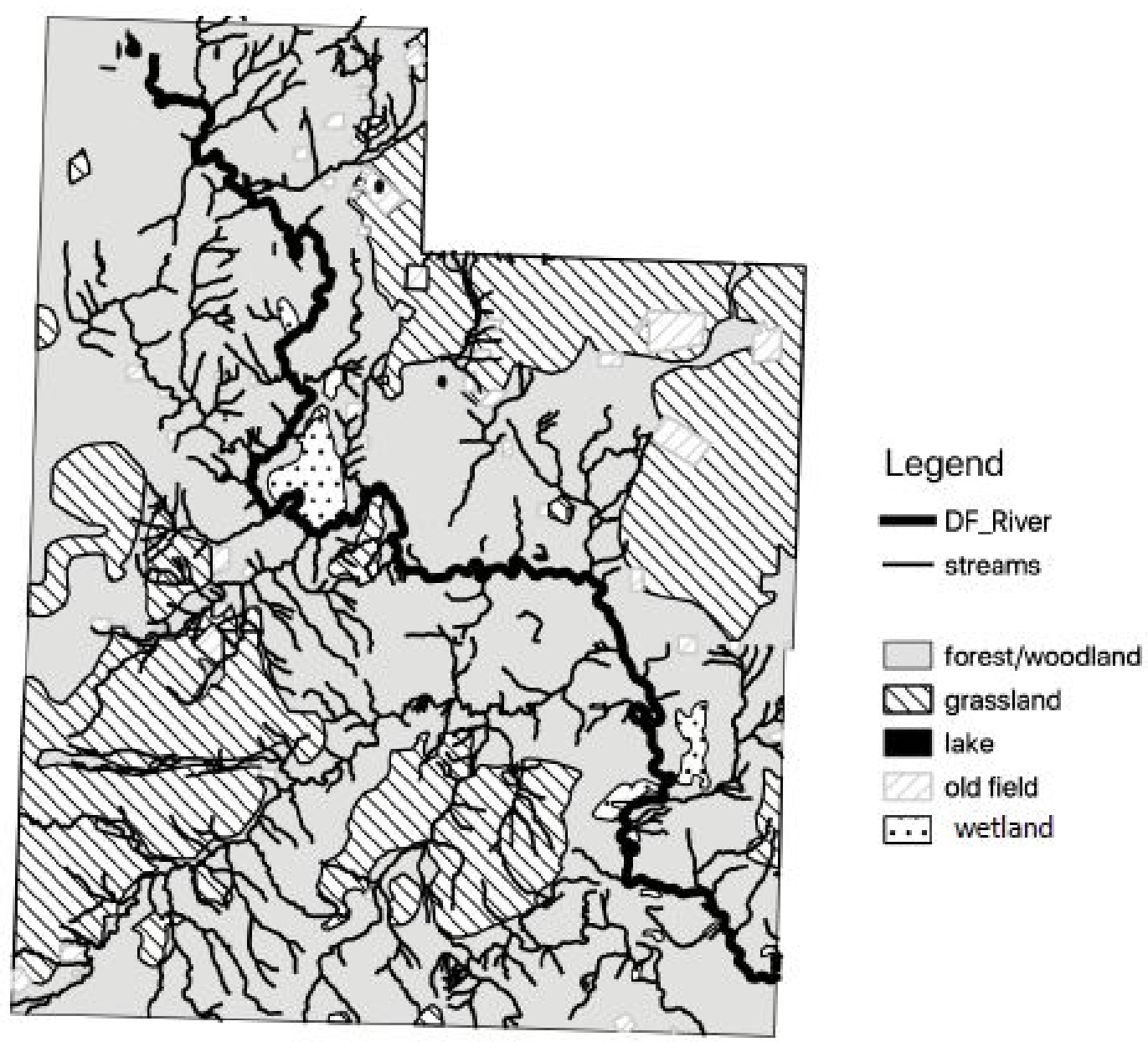

Figure 3 Land cover in the townships encompassing the Deep Fork National Wildlife Refuge, Okmulgee County, Oklahoma, 1897. The map was prepared by digitizing 5 township plats developed by the Public Land Survey in Indian Territory.

Although forest-woodland vegetation occupies the greatest area, it has the fewest number of patches, indicating it is a matrix community type. It is misleading, however, to assume this is all one type of forest. As noted by the surveyors, the area is a combination of upland and bottomland forest. This distinction was not made when the plats were drawn, unfortunately. Grasslands were much smaller in total extent but had a greater number of patches, indicating that grasslands were embedded within the forest-woodland matrix and were likely bordered by woodlands. 
There were 55 agricultural fields averaging 16.5 hectares. Most were bordered by one or more of the 83 built structures (residences or barns, though the surveyors did not denote which type) mapped in the study area. The majority of agricultural fields were in lowland locations where soils tend to be level and fertile. The 93 fenced areas typically enclosed agricultural fields and/or built structures. At this time in American history, fences were constructed to exclude livestock and protect crops (Hart and Mather 1957). Symbology on the plats indicates that the vast majority of fencing was barbed wire, with a smaller quantity of rail fencing.

\section{Bearing Trees}

Surveyors documented the occurrence of 702 stems, or individual trees, representing 22 taxa of woody plants. All taxa encountered by surveyors were also reported as occurring on the DFNWR by Hoagland and Buthod (2017) with the exception of Q. nigra L. and Q. rubra L., nor was either species reported from the adjacent Deep Fork Wildlife Management Area or Eufaula Wildlife Management Area, Deep Fork Unit (Hoagland and Johnson 2005). There are records for both species, however, in Okmulgee County in the Oklahoma Vascular Plants Database (2019). Confounding this is the high number of stems $(n=140)$ and importance value $(\mathrm{IV}=41)$ for $Q$. rubra, indicating that it was a common tree at the time of the survey. Although that possibility cannot be dismissed, surveyors did not collect specimens for identification, so two matters should be considered. First, the DFNWR is on the western extent of the geographic range for Q. rubra, and therefore high abundance is unlikely. Second, some of the 140 individuals were possibly misidentified and in fact are Q. shumardii Buckley or other members of the red oak group that have been documented at the DFNWR $(Q$. falcata
Michx., Q. palustris Münchh., and Q. velutina Lam.).

Several taxa were reported to the genus level only (elm, hickory, maple, ash, birch). Identifications can be posited as to species in two instances. It is reasonable to conclude that the maple reported by surveyors is Acer saccharinum L., a common tree of levees and streamsides in the area, and because $A$. saccharum Marsh. is not reported from the area. The same is true of the birch, which is most likely Betula nigra $\mathrm{L}$. Additionally, only one species of hackberry (Celtis laevigata Willd.) is reported from DFNWR, but C. occidentalis L. is also reported from Okmulgee County (OVPD 2019). Adding resolution to the identification of other trees identified to the genus level is more problematic. For example, two species of ash (Fraxinus americana L. and F. pennsylvanica Marsh.) and two species of hickories (Carya cordiformis [Wangenh.] K. Koch and C. texana Buckley) have been reported from the DFNWR. Likewise, four species of elm have been reported from the DFNWR: Ulmus alata Michx., U. americana L., U. rubra Muhl., and $U$. pumila $\mathrm{L}$. The latter is a non-native species that was not reported from Oklahoma until 1934 (Hoagland 2019). The high number of stems for post oak recorded by surveyors is consistent with the Cross Timbers vegetation (Hoagland et al. 1999). The typical Cross Timbers codominant is blackjack oak, which is third in the order of importance (Table 2). Several species reported reflect the extensive bottomland forests in the area: pecan (Carya illinoinensis), eastern cottonwood (Populus deltoides W. Bartram ex Marshall), water oak (Q. nigra), bur oak (Q. macrocarpa Michx.), and $Q$. palustris. The low number of blackjack oak stems, which approach a ratio of 2:1 post oak:blackjack oak in the Cross Timbers (Rice and Penfound 1959), reflects the eastern location of the sites and the higher diversity of forest types. 
Table 2 Woody plant species recorded by General Land Office surveyors circa 1897 in the townships encompassing the Deep Fork National Wildlife Refuge, Okmulgee County, Oklahoma. The scientific name was derived by the authors from the common name recorded by surveyors. $\mathrm{BA}=$ basal area, calculated in meters $^{2} ; \mathrm{RBA}=$ relative basal area; Stems $=$ the number of individuals stems recorded by surveyors; PS = proportion of stems; IV = importance value.

\begin{tabular}{|c|c|c|c|c|c|c|}
\hline & & $\mathrm{BA}\left(\mathrm{m}^{2}\right)$ & RBA & Stems & PS & IV \\
\hline Post oak & Quercus stellata & 18.53 & 32.80 & 199 & 28.11 & 60.91 \\
\hline Red oak & Quercus rubra & 12.47 & 22.06 & 140 & 19.77 & 41.48 \\
\hline Blackjack oak & Quercus marilandica & 5.88 & 10.40 & 92 & 12.99 & 23.40 \\
\hline Oak & Quercus spp. & 5.90 & 10.44 & 52 & 7.34 & 17.79 \\
\hline Elm & Ulmus spp. & 3.58 & 6.33 & 67 & 9.46 & 15.79 \\
\hline Hickory & Carya spp. & 2.12 & 3.75 & 37 & 5.23 & 8.97 \\
\hline Water oak & Quercus nigra & 1.80 & 3.19 & 33 & 4.66 & 7.85 \\
\hline Black oak & Quercus velutina & 1.29 & 2.29 & 23 & 3.25 & 5.54 \\
\hline Ash & Fraxinus sp. & 0.91 & 1.61 & 14 & 1.98 & 3.59 \\
\hline Bur oak & Quercus macrocarpa & 1.03 & 1.82 & 11 & 1.55 & 3.38 \\
\hline Walnut & Juglans nigra & 0.62 & 1.10 & 8 & 1.13 & 2.23 \\
\hline Pecan & Carya illinoensis & 0.47 & 0.83 & 6 & 0.85 & 1.68 \\
\hline Hackberry & Celtis spp. & 0.38 & 0.67 & 5 & 0.71 & 1.38 \\
\hline Maple & Acer spp. & 0.32 & 0.57 & 5 & 0.71 & 1.27 \\
\hline Cottonwood & Populus deltoides & 0.52 & 0.92 & 2 & 0.28 & 1.20 \\
\hline Persimmon & Diospyros virginiana & 0.22 & 0.38 & 5 & 0.71 & 1.09 \\
\hline Birch & Betula sp. & 0.22 & 0.39 & 3 & 0.42 & 0.82 \\
\hline Sycamore & Platanus occidentalis & 0.07 & 0.12 & 2 & 0.28 & 0.40 \\
\hline Box elder & Acer negundo & 0.05 & 0.09 & 1 & 0.14 & 0.23 \\
\hline Mulberry & Morus rubra & 0.05 & 0.09 & 1 & 0.14 & 0.23 \\
\hline Pin oak & Quercus palustris & 0.05 & 0.09 & 1 & 0.14 & 0.23 \\
\hline Spanish oak & Quercus falcata & 0.02 & 0.04 & 1 & 0.14 & 0.19 \\
\hline
\end{tabular}


Line Notes

There were 205 line notes recorded by the surveyors. Woody plant communities were described as "timber" rather than "forest" in the line notes. The term would appear alone or with the adjectives "heavy" or "scattering", providing a subjective indication of tree density in the area. On three occasions the terms "slough", "swamp", and "swampy" were used to describe the vegetation along the Deep Fork River. Although these terms have multiple definitions, the surveyors were presumably referring to forested wetlands because of the accompanying phrases such as "heavy timber with dense underbrush." Forest understory was described in terms such as "dense underbrush of briars and vines" $(\mathrm{n}=9)$.

Interestingly, the surveyors did distinguish between pastures $(n=8)$ and prairies $(n=75)$, providing evidence of active livestock grazing in the area. The terms appear together in two descriptions, "scattering timber, prairie glade, pasture" and "timber, pasture, dense underbrush, prairie." These are also examples of how surveyors would report the vegetation encountered along the survey line in strings. Grasslands also appeared in bottomlands, as indicated by the description "timber, river bottom and heavy timber, prairie" $(\mathrm{n}=2)$.

The surveyors reported three trees in the line notes that do not appear as a bearing tree: cedar, dogwood, and locust. The cedar is most likely Juniperus virginiana. The dogwood could be either roughleaf dogwood (Cornus drummondii C.A. Mey), flowering dogwood (C. florida L.), or as recently reported from DFNWR, stiff dogwood (C. foemina Mill.) (Hoagland and Buthod 2017). Although both bristly locust (Robinia bispida L.) and black locust ( $R$. psendoacacia L.) were reported from DFNWR (Hoagland and Buthod 2017), the locust in question is most likely honeylocust (Gleditsia triacanthos L.), a common tree of bottomland forests.

\section{CONCLUSIONS}

The PLS records from 1897 clearly illustrate a transformation from bottomland forests, Cross Timbers forest and woodlands, and tallgrass prairie to an anthropogenic landscape. The extent of the transformation is limited, given that agricultural fields are relatively small and scattered. There are many subtleties, however, that are not revealed by the PLS records, such as the impact of livestock. Pastures, for example, were not mapped by the surveyors but were mentioned in the line notes. Livestock, both cattle and swine, likely foraged in prairie and woodland, thus impacting herbaceous species composition. The taxa represented among the bearing trees are part of the modern flora. The abundance of J. virginiana, a native invasive, is low, but this is not surprising considering the percentage of forested land cover. The PLS records have demonstrated utility in describing this landscape of the past, even if it is not a snapshot of the primeval forest.

\section{ACKNOWLEDGMENTS}

The authors thank Gloria Caddell and Chad King for their thoughtful and constructive comments, as well as those of two reviewers.

\section{LITERATURE CITED}

Bourdo E.A. 1956. A review of the General Land Office Survey and of its use in quantitative studies of former forests. Ecology 37:754-768.

Brabander, J.J., R.E. Masters, and R.M. Short. 1985. Bottomland Hardwoods of Eastern Oklahoma. Tulsa (OK): U.S. Fish and Wildlife Service.

Brothers T. 1991. The U.S. General Land Office Survey as a basis for biogeography exercises. Journal of Geography 90:18-26. 
Cottam G. and J.T. Curtis. 1956. The use of distance measures in phytosociological sampling. Ecology 37:451-460.

Cronon, W. 1983. Changes in the Land: Indians, Colonists, and the Ecology of New England. New York (NY): Hill and Wang.

Curtis, N.M., W.E. Ham, and K.S. Johnson. 2008. Geomorphic provinces of Oklahoma. In: Johnson, K.S. and K.V. Luza, eds. Earth Sciences and Mineral Resources of Oklahoma. Norman (OK): Oklahoma Geological Survey.

Duck, L.G. and J.B. Fletcher. 1943. A game type map of Oklahoma. In: A Survey of the Game and Furbearing Animals of Oklahoma. Oklahoma City (OK): Oklahoma Department of Wildlife Conservation.

Fagin, T.D. and B.W. Hoagland. 2002. In search of the forest primeval: The use of land survey records in reconstructing past landscapes and evaluating human impact. North American Geographer 4: $1-20$.

Fagin, T.D. and B.W. Hoagland. 2010. Patterns from the past: modeling Public Land Survey witness tree distributions with weights-of-evidence. Plant Ecology 212:207-217.

Flannery, T. 2002. The Eternal Frontier: An Ecological History of North America and Its Peoples. New York (NY): Grove Press.

Galatowitsch, S.M. 1990. Using the original land survey notes to reconstruct presettlement landscapes in the American west. Great Basin Naturalist 50:181-191.

Goudie, A. 2005. The Human Impact on the Natural Environment. Oxford (England): Blackwell Publishing.

Hanski, I. 2011. Habitat loss, the dynamics of biodiversity, and a perspective on conservation. Ambio 40:248-255.

Hart, J.F. and E.C. Mather. 1957. The American fence. Landscape 6:4-9.

Hoagland, B.W. 2000. The vegetation of Oklahoma: a classification for landscape mapping and conservation planning. Southwestern Naturalist 45:385-420.

Hoagland B.W. 2006. Township and Range Survey System, In: C.R. Goins and D. Goble, eds. Historical Atlas of Oklahoma. Norman (OK): University of Oklahoma Press.

Hoagland, B.W. 2019. An assessment of invasive status of non-native vascular plants in Oklahoma. Phytoneuron 49:1-18.

Hoagland, B.W. and A.K. Buthod. 2017. Vascular flora of the Deep Fork National Wildlife Refuge, Okmulgee County, Oklahoma. Castanea 82:32-45.

Hoagland, B.W., I. Butler, F.L. Johnson, and S.M. Glenn. 1999. The Cross Timbers. In: Anderson, R.C., J. Fralish, and J. Baskins, eds. Savannas, Barrens, and Rock Outcrop Communities of North America. Cambridge (England): Cambridge University Press.

Hoagland B.W. and F.L. Johnson. 2005. Vascular flora of the Deep Fork River in Okmulgee, Creek, and Okfuskee Counties, Oklahoma. Publications of the Oklahoma Biological Survey 6:15-29.

Hoagland, B.W., J. Messick, M. Rahman, and T. Fagin. 2013. Vegetation patterns in Wichita Mountains National Wildlife Refuge, Oklahoma; an analysis of General Land Office Survey records from 1874 and 1905. Publications of the Oklahoma Biological Survey 12:1-14.

Hunt, C.B. 1974. Natural Regions of the United States and Canada. San Francisco (CA): W.H. Freeman.

McGarigal, K., S.A. Cushman, and E. Ene. 2012. FRAGSTATS v4: Spatial Pattern Analysis Program for Categorical and Continuous Maps. Amherst (MA): University of Massachusetts. https://www.umass.edu/landeco/resear ch/fragstats/fragstats.html

Oklahoma Climatological Survey. 2019. Climate Facts by County. https://climate.ok.gov/index.php/clima te/county climate//local data (1 November 2019) 
Oklahoma Vascular Plants Database (OVPD). 2019.

https://www.biosurvey.ou.edu/atlasdes c.html (1 November 2019)

Rice E.L. and W.T. Penfound. 1959. The upland forests of Oklahoma. Ecology 40:593-608.

Schulte L.A. and D.J. Mladenoff. 2001. The original US Public Land Survey records: their use and limitations in reconstructing presettlement vegetation. Journal of Forestry 99:5-10.

Shutler A. and B.W. Hoagland. 2004. Vegetation patterns in Carter County, Oklahoma, 1871. Proceedings of the Oklahoma Academy of Science 84:19-26.

Sparwasser, S.G., V.A. Bogard, and O.G. Henson. 1968. Soil Survey of Okmulgee County, Oklahoma. Washington (DC): United States Department of Agriculture.

Stewart, L.O. 1935. Public Land Surveys: History, Instructions, Methods. Ames (IA): Collegiate Press.

Thomas, R. 2010. Pre-settlement cross timbers in central Oklahoma. [Master's thesis]. Norman (OK): University of Oklahoma. Trewartha G.T. 1968. An Introduction to Climate. New York (NY): McGraw-Hill.
Turner II, B.L. and W.B. Meyer. 1991. Global land-use and land-cover change: An overview. In: Meyer, W.B. and B.L. Turner II, eds. Changes in Land Use and Land Cover: A Global Perspective. Cambridge (England): Cambridge University Press.

United States Fish and Wildlife Service. 2019. Deep Fork National Wildlife Refuge. https://www.fws.gov/refuge/deep for k/ (1 November 2019).

Van Auken O.W. 2000. Shrub invasions of North American semiarid grasslands. Annual Review of Ecology and Systematics 31:197-215.

Wenger, K.F. 1984. Forestry Handbook, $2^{\text {nd }}$ ed. New York (NY): Wiley-Interscience. White, C.A. 1983. A History of the Rectangular Survey System. Washington (DC): U.S. Department of the Interior, Bureau of Land Management.

Whitney G.G. and J.P. DeCant. 2001. Government land office survey and other early land surveys. In: Egan, D. and E.A. Howell, eds. Historical Ecology Handbook. Washington (DC): Island Press. 